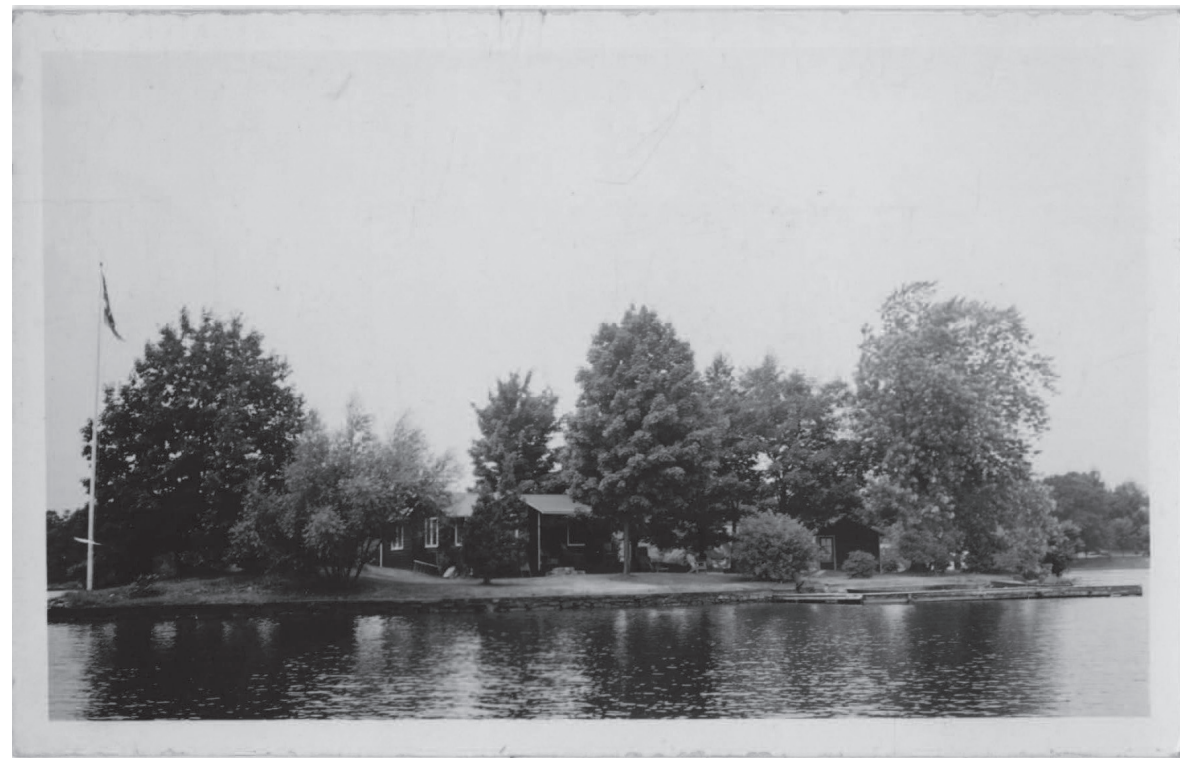

Fig. 1, Stanley Island, 1940s. Photo: Bain Family Archive 


\title{
WALT WHITMAN IN CANADA: THE SEXUAL TRINITY OF HORACE TRAUBEL AND FRANK AND MILDRED BAIN
}

\author{
Marylin J. McKay
}

\section{Introduction: City and Country Shrines}

Twenty-Five MiLEs EAST of Kingston, Ontario, a small island sits on the Canadian side of the St. Lawrence River within view of Wellesley State Park on the American side (Figure 1). Called Stanley Island since at least 1901, it is part of the Thousand Islands, a region that has been popular with Canadian and American tourists since the 1870s. During the summer of 1880 Walt Whitman visited the Thousand Islands with his friend, Dr. Richard Maurice Bucke, the Superintendent of the London (Ontario) Insane Asylum. Whitman and Bucke would have come close to Stanley Island since, according to Whitman's diary and Bucke's letters, they stayed twenty-five miles east of Kingston at the Hub House hotel on "a little mote of an island" on the American side within view of Wellesley Island State Park. ${ }^{1}$

In 1938 Whitman's connection to the Thousand Islands-however fleeting-encouraged ardent Canadian Whitmanites, Francis (Frank) Wayland Bain (1875-1959), a banker, and his wife Mildred Louise Jackson Bain (1876-1962) to purchase Stanley Island. The Bains had read Whitman's Canadian diary soon after it was published in $1904 .^{2}$ A few years later they had made pilgrimages to Whitman's family home at West Hills, Long Island, and to the house in Camden, New Jersey, where Whitman resided from 1884 to 1892 . In keeping with Whitman's scorn for elaborate dwellings, the Bains provided Stanley Island with a small cedar cottage and a sleeping cabin, neither of which they equipped with plumbing or electricity. ${ }^{3}$ Within the cottage they set up a library of Whitman's writings and those of many of the social and political activists who believed Whitman supported their causes. These causes included democracy, socialism, communism, anarchism, pacifism, mysticism, human rights, the labor movement, universal brotherhood, free love, birth control, women's suffrage, liberal attitudes toward homosexuality, gentle forms of child-rearing, and non-traditional forms of spirituality, although, as so many scholars have pointed out, Whitman 


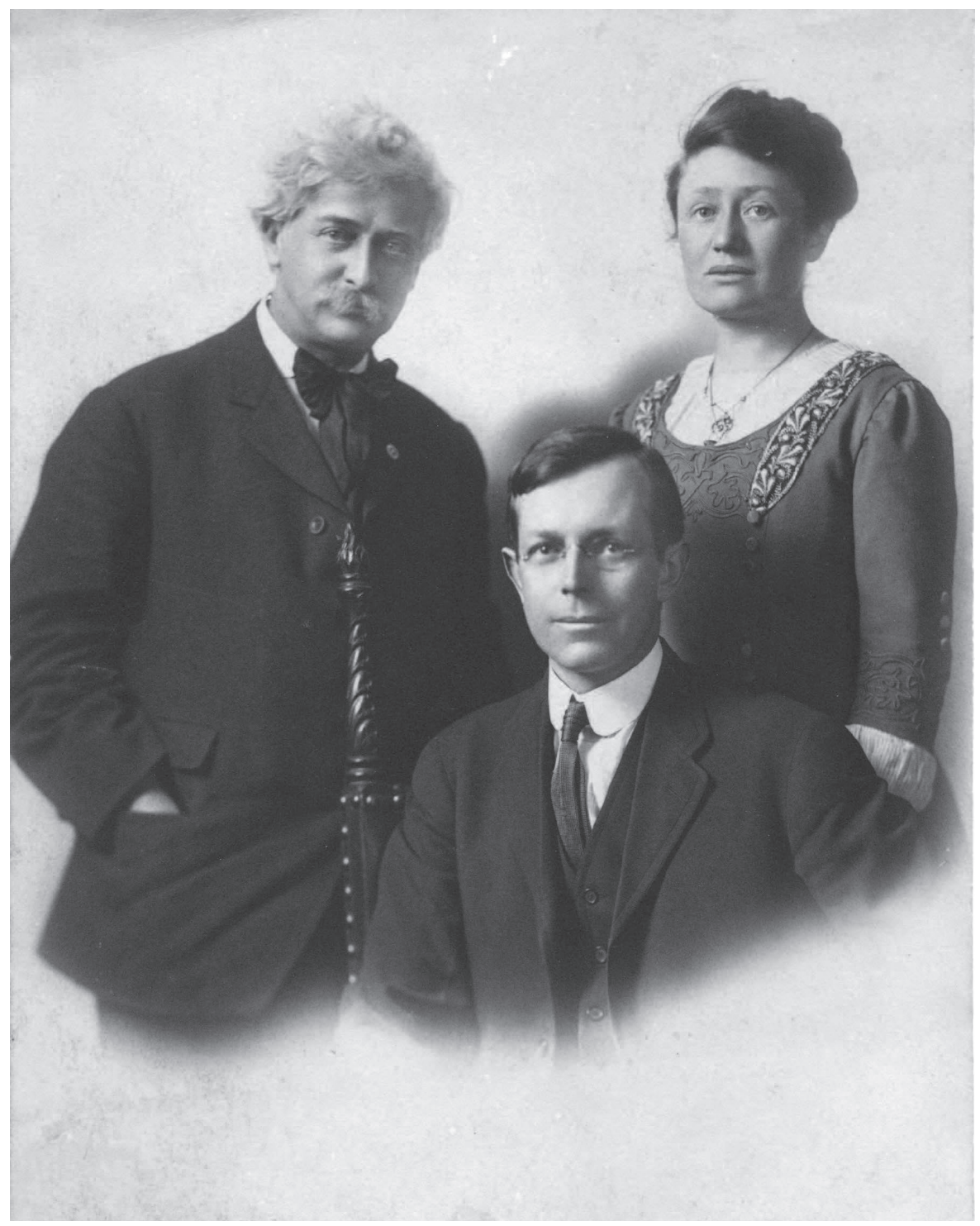

Fig. 2, Horace Traubel, Frank Bain, and Mildred Bain, c. 1912. Photo: Bain Family Archive

openly supported only some of them. Above the bookshelves the Bains placed photographs of Whitman and his most passionate disciple Horace Traubel. Rounding out this installation, which is still intact, the Bains mounted photographs of themselves with Traubel (Figure 2), with whom they were intimate friends from approximately 1908, photographs of 
other Whitmanites, and an image of the famous funerary sculpture of Queen Nefertiti. The latter acted as a reference to Whitman's interest in Egyptian constructions of immortality and to his belief in a unity of time and space. ${ }^{4}$

Just outside the door of the Stanley Island cottage, the lilac bushes had a direct connection to Whitman. In honor of Whitman and one of his most beloved poems, "When Lilacs Last in the Dooryard Bloom'd," his followers wore lilacs on their lapels at memorial meetings held on May $31^{\text {st }}$, the anniversary of Whitman's birth. ${ }^{5}$ It was after the 1911 meeting in New York that the Bains visited Whitman's Long Island home along with two of their Canadian Whitmanite friends, Henry and Georgina Saunders. ${ }^{6}$ The Saunders took some lilac shoots from the site and planted them at their Toronto home. When the Bains purchased a house in Toronto in 1934, the Saunders gave them some of the Whitman lilacs for their new dooryard. In 1939 the Bains replanted some of them in the dooryard at Stanley Island. ${ }^{7}$

At the end of each summer on Stanley Island, Mildred and Frank would return to their Toronto home (now demolished). Designed and furnished in a rustic style, images of it evoke Whitman's adulation of common laborers and Traubel's support for the Arts and Crafts Movement. $^{8}$ This house once contained the same type of reading material as the island cottage as well as many works of art that Traubel gave the Bains, including a photograph of Traubel by Clarence Hudson White commissioned by William F. Gable; oil and pastel landscapes, cityscapes, and portraits of Traubel by Arthur Goodwin; a pastel of Traubel by an unknown artist; and dozens of Japanese prints. ${ }^{9}$ In addition the Toronto house contained about a hundred other photographs of Traubel and many of other Whitmanites; decades of correspondence between the Bains and Traubel and between the Bains and other Whitmanites; documentation of the extensive financial and editorial assistance the Bains gave Traubel; and items that Traubel received directly from Whitman and gave to the Bains (such as photographs of Whitman and his mother). ${ }^{10}$

Many Whitman scholars have briefly noted that Frank and Mildred Bain were participants in the international cult of Whitman, but no one has given them the attention they deserve. My in-depth study of the Bains contributes to Whitman scholarship in three ways. First, it makes use of unpublished material from various institutional archives and the Bain Family Archive to show how an ordinary, middle-class, married couple, living in the ultra-conservative environment of early twentieth-century English Canada, came to support many of the causes with which Traubel and other social and political activists associated Whitman. Thus it provides a greater understanding of Whitman's international audience at this time. Secondly, in opposition to what 
other scholars have said, it demonstrates that the Bains were the most active of the early twentieth-century Canadian Whitmanites. ${ }^{11}$ Thirdly, it establishes the likelihood that Traubel had a sexual relationship with both Frank and Mildred Bain; that Traubel fathered Mildred's two children, Betty Bain (1912-1996) and Paul Bain (1916-1972); and that Traubel and the Bains conducted this liaison under the aegis of what they believed to be Whitman's thinking on the connection between the sexual and the spiritual. As a result my study sheds further light on interpretations of Whitman's sexuality.

\section{Whitman, Traubel, and the Sacro-Sexual}

Whitman maintained that he wrote Leaves of Grass as the basis of a new American religion or form of spirituality that would render American society so moral that laws would be unnecessary. Its most important doctrine was "comradeship" or love for one's fellow human beings. Whitman also urged his readers to understand that their bodies were part of nature and that nature was imbued with the divine. Men and women were to respect this state by rejecting not only prostitution and pornography but also prudishness about sexuality. In addition men and women were to make comradeship the basis of sexual activity. While there is no good evidence that Whitman ever had a sexual involvement with a woman, or produced any children, various lines of his poetry glorify heterosexual relationships and, presumably, the children of such unions. At the same time, Whitman flagrantly and famously claimed to have fathered six children, "illegitimate of course."12 Most scholars doubt this claim. Still, it suggests that Whitman condoned loving sexual unions between men and women who were not married, as well as any ensuing "love children."

Furthermore, Whitman strongly encouraged men, as good comrades, to be physically affectionate with each other. As he said, he looked forward to a time when there would be "running like a half-hid warp through all the myriad audible and visible worldly interests of America, threads of manly friendship, fond and loving, pure and sweet, strong and life-long, carried to degrees hitherto unknown-not only giving tone to individual character, and making it unprecedentedly emotional, muscular, heroic, and refined, but having the deepest relations to general politics." "13 Given statements of this type, the homoerotic nature of his "Calamus" cluster of poems in Leaves of Grass, and his friendships with men who were homosexual, many of Whitman's readers have wondered if comradeship allowed for sexual relationships between men. Whitman adamantly declared it did no such thing.

Horace Traubel preached the same doctrine. Comradeship was the "thread electric" that runs "from soul to soul ... mends breaks or 
heals wounds." "14 Therefore it could moralize society. Sexual relations should not be "insanely indulged" or "insanely suppressed." Nor were legal marriage and legitimate birth sacrosanct. As Traubel asked his readers, "Is love an affair you can settle with the marriage bed ... [w]ith children of your flesh?" He responded by saying, "Love is an overflow ... You could not say no when love says yes. You are swept away ... The lover is to go where he pleases. To frequent the highways." ${ }^{15}$ Equally in line with Whitman, Traubel developed friendships with men of the "intermediate sex," yet publically denied support for sexual activity between men. As Traubel said a year after Whitman died: "Homosexuality is a disease - it is muck and rot-it is decay and muck - and Walt uttered the master-cries of health, of salvation and purity, of growth and beauty." 16 Traubel may well have made this denial — as Whitman may have made his - not because they rejected sexual relations between men but because, at a time when homosexuality was illegal and starting to be viewed as a disease, they wanted to deflect critics from focusing on the parts of Leaves of Grass that supported male comradeship. As Juan A. Herrero Brasas has recently put it, Whitman intended comradeship to convey "a spectrum of love" that was part of his "messianic project."

Certainly Traubel contradicted his negative position on homosexuality later. In 1913, for example, in an article in The Conservator, the monthly journal Traubel produced from 1890 to 1919 to disseminate Whitman's views, Traubel said that recent studies of homosexuality were honest and scientific and that it was impossible "to cut and dry [sex] into a narrow formula . . . to wholly dissever the masculine from the feminine." He also proclaimed, "How normal some things are which we have so far tried to account for as disease." He then suggested to his readers that they "go with sex away from the usual into the special." 18 Moreover, as other scholars have argued, and as I will too, Traubel openly practiced what he preached as he not only married and had legitimate children but also very likely had extra-marital relationships with both men and women and fathered "love children." Since Traubel devoted his life's work to Whitman, it is reasonable to assume he believed that Whitman would have regarded these involvements as both sacred and moral - in other words, as forms of comradeship.

\section{Traubel and Sacro-Sexual Comradeship before the Bains}

In 1891 Horace Traubel married Anne Montgomerie Traubel (18641954) in a ceremony that took place in Whitman's house in Camden. Sixteen years later, Anne, at least, was highly satisfied with their sexual life. As she said to Horace, "I think very few people love each other as you and I love each other, Horace . . . I love you, I hold you upon your soft, palpitating refuge. Joy! Love! Fruition!"19 Yet as early as 
1893, as the plausible research of Joann P. Krieg and Harry G. Cocks demonstrates, Traubel began a sexual relationship with Philadelphia musician and Whitmanite Philip Dalmas. It seems to have lasted on and off until $1895 .{ }^{20}$ Bryan K. Garman and Michael Robertson have convincingly argued that in 1899 Traubel became sexually involved with Boston dentist and Whitmanite Gustave Percival Wiksell (18551939). This relationship ended in 1907, I would contend, at least in part because Traubel had entered into a sexual liaison with Rosalie Goodyear (1886-1969?). ${ }^{21}$

Horace Traubel met Rosalie Goodyear through Paul Fournier (1888-1961), a photographer and member of the Roycrofters, an Arts and Crafts community in East Aurora, New York. In 1904, after Rosalie stopped receiving support from the Goodyear family, she took a clerical job at the Roycrofters where she met and soon married Paul. He introduced Rosalie to Traubel's writings. ${ }^{22}$ In 1906 Rosalie and Paul left the Roycrofters. They spent part of the next three years in Philadelphia, where Horace kept his office (a short distance across the Delaware River from his home in Camden), and part in New York, where Horace frequently visited his bohemian Greenwich Village friends. ${ }^{23}$ In early 1909 Rosalie became pregnant. A few months later she and Paul moved to Illinois where Rosalie gave birth to Désirée Fournier. It is reasonable to suggest, on the basis of Rosalie's letters to Horace (none of his to her have surfaced), that Horace was the child's father and that Rosalie, at least, saw their alliance as sacred. As Rosalie said, "I grew to love, indeed worship Traubel beyond all possibilities of expression. I literally bathed myself in the essences of his soul that flowed forth like a divine elixir." 24 In January of 1910, eight weeks after her daughter's birth, Rosalie told Horace that she was calling the baby "Horatia"- "since you will have it so." She then pleaded with Horace to visit: "Every day I look for you to come and take her in your arms." ${ }^{25}$ Rosalie also called Horatia her "wee white lilac" and so connected the child to Whitman. ${ }^{26}$ In March Rosalie claimed that Horace had a duty to visit Horatia: "Every little while you will have to come and stay where I am because of Horatia" (italics added). She then said, "I wish so often [Horatia] had really been a Horace." 27 But Horace did not go to Illinois, likely because by this time he had become intensely involved with the Bains. ${ }^{28}$

\section{Whitman, Traubel, and the Bains: The Early Years}

The Bains' interest in Whitman and his followers began in 1904, four years after their marriage in Trinity Anglican Church in the small Ontario town of Simcoe, about ninety miles south-west of Toronto. Mildred was born in Simcoe to Elizabeth Elsie Walsh and George Bruce Thomas Jackson. She attended church, finished high school, 
and completed advanced music lessons there. Frank was born in the small town of Tilsonburg, not far from Simcoe, to Thomas C. Bain, a civil servant, and Laura Van Norman. His family gave him a similar upbringing, but they also provided him with an introduction to Bucke's writings on Whitman. ${ }^{29}$ In 1904, when Frank and Mildred were living in Burlington, Ontario, about 30 miles west of Toronto, Frank's Aunt Mary Priest, a psychic and social activist, sent him a copy of Dr. Bucke's Cosmic Consciousness (1901).

In Cosmic Consciousness Bucke argued that the world was going through a spiritual evolution in which human levels of consciousness were expanding. Eventually everyone would be able to see through the barriers that separated the material and spiritual worlds. Consequently they would become more moral. According to Bucke, Whitman had reached the highest level of cosmic consciousness before he died. Bucke claimed to have had his own level of cosmic consciousness raised after reading Whitman. For a brief moment one day he became "wrapped" in a "flame-colored cloud." After the cloud disappeared he was left with "a sense of exultation, of immense joyousness accompanied ... by an intellectual illumination quite impossible to describe." 30 Soon after reading Bucke, Frank Bain experienced the same phenomenon: "The sense of being enveloped in a rose coloured mist came over me ... The rose colour faded away in the course of a few hours to be succeeded in the days following by a sense of inexpressible lightness and joy ... There was a sense of seeing beyond the surface of things to their essence ... The effect of those few days of insight has been an inner joy and assurance that abides." 31

This event led Frank to read Whitman and encourage Mildred to do the same. Discovering Whitman persuaded them to explore Traubel's writings and to contact him. Thus the Bains set out on a path which would take them from a conservative Victorian society to a modern world with Whitmanian ethics dispensed by Traubel as their guide. Frank's journey is clearly documented in his correspondence with Traubel. Mildred's may be easily garnered from remaining letters (many have mysteriously disappeared) and four other rich sources: Frank and Horace's letters to each other in which they discuss Mildred; Mildred's poems and articles in The Conservator; Mildred's inscriptions in books she gave her children; and Mildred's hagiographic publications on Traubel. ${ }^{32}$

Frank wrote his first letter to Traubel in December of 1905. Over the next year he sent others in which he spoke of Whitman and Traubel's writings and the Walt Whitman Fellowship. He also purchased a subscription to The Conservator. ${ }^{33}$ By late 1906 Frank and Horace's letters had become more personal and Frank had made his first offer of financial aid. ${ }^{34}$ From 1907 until 1919 Frank would send Horace between $\$ 25$ and 
$\$ 100$ a month to help with personal debts and the costs of publishing The Conservator. In 1907 Frank was earning $\$ 2000$ a year at the Trader's Bank. By 1919 his salary had risen to $\$ 3000$. Frank did, therefore, turn over a substantial portion of his income to Horace. Ironically, five years before Horace first accepted Frank's contributions, he had left a job in a Philadelphia bank because his employer insisted he refrain from publically airing his socialist views.

In early 1907 Mildred sent her first letter to Horace. As Frank explained with reference to this particular letter, Horace's work was "a liberation for both of us." ${ }^{35}$ A few weeks later Horace sent Frank and Mildred one of Whitman's cancelled checks. They treasured it like the relic of a saint. In September of 1907 Mildred submitted a poem to The Conservator. Entitled "Oh Dear New Comrade," it states that she now sees the sacred aspects of love and sexuality as Whitman and Traubel did. Until recently her body had been "shackled" and "cramped." But now she could perceive "the full glories of the body and the soul as equally God-given" and so could "be a wife to more than my husband ... a lover to all." She will "gently loosen ... [t] he bloodless clinging fingers of tradition ... [a] nd hereafter . . . give my love freely and naturally to man as well as woman." ${ }^{" 36}$ In November she wrote to Horace in an exuberant tone: "Oh! this wonderful sense of nearness today, my comrade! as if I could put my hands out and touch you. Touch your beautiful hair-hear you breath! . . If you could see me other times, snatching up the Chants [Traubel's Whitman-style prose of 1904] or perhaps one of your letters and ... laughing and dancing about the house with it! I can't begin to tell you what an inspiration it all is to me." 37

\section{Traubel, the Bains, and Sacro-Sexual Comradeship}

Frank, Mildred, and Horace corresponded regularly throughout 1908, while Horace began to send them books. Each was inscribed to Frank or Mildred or both, depending on the topic. Over the next eleven years Horace would send hundreds of books (most of which he received for review in The Conservator). Many of them were concerned with modern views of heterosexuality and homosexuality such as Edward Carpenter's Love's Coming-of-Age: A Series of Papers on the Relations of the Sexes (1905), T. Arnold Haultain's Hints for Lovers (1909), and Oscar Wilde's De Profundis (1906). Traubel also sent the Bains hundreds of picture postcards, sometimes more than one a day. Many of them had images of nudes by Rodin and other modernist artists. Several depicted a nude female with red hair-like Mildred's - surrounded by nude infants. Another illustrated the myth of Ganymede and the eagle in which the divine Zeus, more known for his heterosexual extra-marital relationships, had a homosexual one. Thus, it would seem that Traubel was 
gradually teaching the Bains to equate heterosexual and homosexual love.

In May of 1908 the Bains attended the Walt Whitman memorial meeting at the Brevoort Hotel in Greenwich Village and finally met Horace as well as some of his Whitmanite friends including Goodwin and Wiksell. ${ }^{38}$ Writing to Horace after this visit, Frank said, "Those beautiful days . . . They mean so much to me and Mildred too . . . in everything I do your love makes me strong." ${ }^{39}$ Over the next few months Frank regularly complained in a covetous way that he did not hear from Horace often enough. For example, in December he said, "Just a word [from you] would be better than food for me." 40 At the same time Frank made it clear that Mildred shared his desire to see more of Horace. By this time the Bains were "Traubelites" as much as they were Whitmanites. ${ }^{41}$

In May of 1909 Frank and Mildred attended the Walt Whitman meeting in New York and spent time with Horace and others in his circle. In early July, Frank took a leave of absence from the bank because, as he said, the capitalistic nature of the banking business was destroying his soul. ${ }^{42}$ However, Frank's activities during this leave suggest that he also wanted an opportunity to explore his sexual attraction to men. Frank started his leave with several days in New York where he stayed with Horace at the Brevoort. Then he left for England supplied with introductions from Horace to Whitman's followers in Bolton. Some of these followers were likely homosexual. ${ }^{43}$ Another introduction from Horace allowed Frank to spend several days with English social activist Edward Carpenter (1844-1929) and his male lover George Merrill (1866-1928) at their home in Millthorpe. ${ }^{44}$ Frank had been familiar with Carpenter's work before he met Traubel. In 1904, along with Bucke's Cosmic Consciousness, Aunt Mary Priest had given Frank a copy of Carpenter's From Adam's Peak to Elephanta: Sketches in Ceylon and India. ${ }^{45}$ While this book is for the most part a travel-log, it also posits a relationship between spirituality and sexual activity. In 1905 Frank had purchased Carpenter's Toward Democracy, a book of poems some of which have homoerotic themes. By the time Frank travelled to England he likely knew of Carpenter's struggles to live openly as a homosexual and his earlier writings on homosexuality, such as his Homogenic Love (1894) and The Intermediate Sex: A Study of Some Transitional Types of Men and Women (1908). As Frank was boarding his ship in Liverpool, Carpenter sent him a copy of The Intermediate Sex. Frank glued the wrapper to the book's inside cover and placed his invitation to Millthorpe inside his copy of Adam's Peak. When Frank's ship docked in New York he spent a few more days with Horace at the Brevoort and then returned to Montreal and Mildred. 


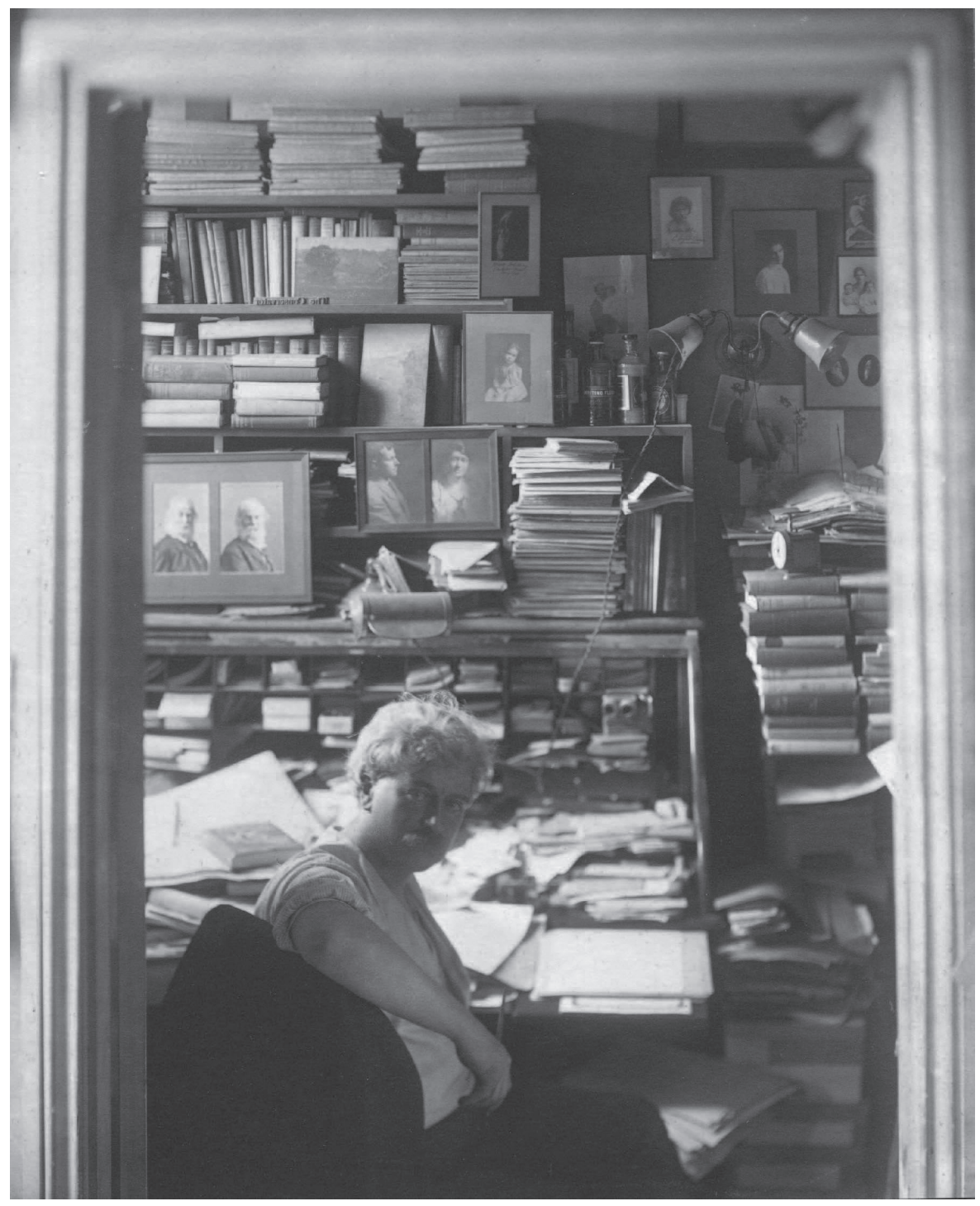

Fig. 3, Horace Traubel in his Philadelphia office with photographs of Frank and Mildred Bain (directly above his head), c. 1912.

Before Frank left for England, Mildred had submitted a poem, "Love Said to Me," to The Conservator. It attempts to persuade "a dear one" to live together under conditions that "will be free as air" since she does not want "to take possession." ${ }^{\text {"46 }}$ It is difficult to imagine that the "dear one" could be anyone other than Frank; therefore, it is pos- 
sible that the "conditions" were her understanding of his sexuality. Just after Frank returned from England, Horace sent Mildred Modern Love: An Anthology, edited by Horace's friend Mitchell Kennerley, a radical Greenwich Village publisher. It includes poems that support both heterosexual and homosexual love. Traubel also sent Mildred a copy of "The Right Voice," a short story by Anita Gabrielle Lavrack from Smart Set, a journal published by Kennerly. ${ }^{47}$ Lavrack's story is about a pair of lovers, one male, one female. It ends with a quotation from Whitman's "Full of Life Now," the last of the "Calamus" poems in Leaves of Grass. However, Lavrack substituted "lover" for Whitman's "comrade" so that the line reads, "Fancying how happy you were, if I could be with you, and become your lover." Since the story has little else to commend it, it seems likely that Horace sent it to Mildred because it equates "comrade" and "lover" and thus promotes free love as Kennerley and so many other Greenwich Villagers did.

In October Horace arranged for the Bains to receive the Clarence Hudson White portrait mentioned above. Frank was delighted: "It makes me want to laugh and sing just for joy." ${ }^{48}$ In November Frank responded in distressed tones to a letter in which Horace had accused Frank of "disloyalty": "Your letter was a terrible blow to me." ${ }^{\prime 9}$ While Horace's letter is missing, it is clear from Frank's that Horace had been giving his opinion on the promotion-and thus a greater involvement in capitalism - that Frank had just been offered by the bank. In the end Frank took the promotion and its requisite move to Montreal and hung a photo of Horace in his office.$^{50}$ Horace continued to accept Frank's financial support - and thus indirect income from a bank-and hung pictures of Mildred and Frank in a prominent position in The Conservator office (Figure 3).

\section{Mildred's First Pregnancy}

In early 1910 Frank invited Horace to Montreal. In plaintive tones he said, "Mildred needs you and I want you mighty bad." 51 Three weeks later, at a time when making a long-distance call was a major undertaking, Mildred and Frank tried to telephone Horace "just to hear your voice." ${ }^{52}$ Horace arrived on March $9^{\text {th }}$. He stayed two weeks. The day he left, Frank and Mildred were devastated as Frank's letter makes clear: "Horace, I miss you oh how I miss you ... [a]ll day long my heart's been crying out for you fit to break ... [Mildred and I] are now in the little room [on the top floor of the Montreal house] thinking of you and our sacred days together." ${ }^{33}$ At the end of May Frank and Mildred attended the Walt Whitman memorial meeting in New York. Shortly before they set out, Frank wrote to Horace: "All day yesterday I was way off there in New York with you in the Brevoort in room 73 . The room is haunted 
alright. It was for me last summer." 54 Then he added, "Don't forget to get adjoining rooms for us." 55 Mildred set three of Horace's poems to music and sang them at the meeting. After returning to Montreal, Frank wrote to Horace: "I long to be back there again with you and Mildred . . . Oh how my heart longs for it." ${ }^{56}$ These letters leave little doubt that Frank loved Mildred and wanted to maintain his marriage but that he craved Horace.

Horace spent two months with the Bains in Montreal in the summer of 1910. During this time Mildred became pregnant. It seems likely that Horace was the father. Mildred does not seem to have conceived during the first ten years of her marriage, but between 1910 and 1916 she conceived four times. Each conception took place while Horace and the Bains were together for weeks or months at a time. The length of these visits cannot entirely be explained by Horace's professional needs. It is true that during the summer of 1910 Frank and Mildred helped Horace put Optimos together (Horace's Whitman-like volume of poetry) for publication in the fall. In addition the Bains began to edit parts of The Conservator on a regular basis. But Horace could just as easily-and without incurring travel expenses that he could ill afford-have done the work at home where Anne and his daughter Gertrude (1892-1983) would have assisted him as they always had. ${ }^{57}$ Furthermore, Horace used much of this time in Montreal to go to lectures, theatres, parks, and restaurants, and to shop with Frank and Mildred. He also took a tour of Quebec City, possibly with Frank and Mildred. In a letter to his friend, the American artist Marsden Hartley (1877-1943), he said that he was working but had originally come to Montreal to "loaf." 58 Perhaps Horace was using "loaf" as a euphemism for sexual activity as Whitman did in "Song of Myself." In this poem Whitman calls for his soul, which is simultaneously a person of unspecified gender, to "Loafe with me on the grass." He then remembers an earlier episode of "loafing" with the same person: "How you settled your head athwart my lips and gently turn'd over upon me, / And parted the shirt from my bosom-bone, and plunged your tongue to my bare-stript heart" $(L G, 33)$. Horace would have been familiar with these lines and may well have expected Hartley, who was homosexual and a Whitmanite, to have known them too. Wiksell, who had remained on good terms with Horace after their affair, likely used similarly discreet language to acknowledge Horace's sexual relationship with the Bains. In the summer of 1910 he sent a letter to Horace in Montreal asking him to "Tell Frank and Mildred I am proud of their love," as if it was something unusual that he could not describe more graphically. ${ }^{59}$

Whatever transpired between the Bains and Horace during the summer of 1910 was certainly remarkable, if Horace's letters of September and October to Frank — which regularly refer to Mildred-may 
be taken as a measure. On September $17^{\text {th }}$ Horace wrote: "Well, count a few days and weeks ahead. Then I'll go to see you again. In the flesh ... into the ... room in the little house [in Montreal] which has known our love." ${ }^{60}$ On the $25^{\text {th }}$ he sent three letters. The first said: "Your love and Mildred's love are inspirational ... I thrive under it." The third said: "I am somehow strangely sweetly at peace with what is happening and will happen in my troubled life. $\mathrm{O}$ darling brother. $\mathrm{O}$ darling brother." ${ }^{61}$ On September $30^{\text {th }}$ Horace wrote: "I do nothing but dream of the little room and getting there." On October $2^{\text {nd }}$ he was equally fervent: "[Frank] I breathe you in and feel deep attachment and joy." Three days later he declared, "[I have] this aching eager love for you." 62 Frank responded: "Years before I knew you I felt that strange something drawing us together . . . oh Horace I know I am reticent. Words seem ineffectual." He then equated his love for Horace with his love for Mildred as he said, "but I love you and Mildred" (italics added). ${ }^{63}$

On October $5^{\text {th }}$ Frank sent Horace a letter in which he said that Mildred had suffered a miscarriage and that their "hopes [were] dissipated." ${ }^{\prime 64}$ The fact that Frank could convey such information at a time when miscarriages were rarely discussed, especially between two men, adds some strength to the suggestion that Horace was the father. Horace's letter of October $7^{\text {th }}$ - sent before he received the news of the miscarriage-indicates the level to which his passion for both Bains had developed by this time. He told Frank and Mildred that he was "suffocating," that he felt "choked" living with Anne and Gertrude in Camden. He said he had to pretend to be happy for Anne's and Gertrude's sake, but his true home was now with the Bains, with Frank and Mildred: "You and Mildred, Mildred and you, have given me life, a home, peace, faith . . . I am alive."65

\section{Mildred's Second and Third Pregnancies}

Horace returned to Montreal in early January of 1911 after Frank had begged him to come and said, as if he was offering his wife to Horace, that "Mildred is looking more beautiful than ever." 66 During this visit, which lasted about six weeks, Mildred became pregnant again. After Horace left, Frank wrote, "All day long my heart has been crying out for you. I miss you so." ${ }^{67}$ A month later he said, "All day long my heart has been way off there in the Brevoort . . looking for you." ${ }^{68}$ On May $19^{\text {th }}$ Frank told Horace that Mildred had suffered "another mishap and our dear hopes are once more disappointed. The doctor has been twice today and we were in hopes it could be averted, but it was no use." ${ }^{99}$ Horace's urgent reply in a telegram rather than a letter and his use of "our" and "we" suggest his involvement in the pregnancy: "I have the bad news. Do not worry, though things don't go our way. We are sure to 
win out." 70 Ten days later the Bains travelled to the Whitman memorial meeting in New York. In early June Frank would refer to this visit as "so much like heaven to me." now a part equally spiritual. As he said, "Frank, dear lover my body reaches out to you. You and Mildred and I seem to be a Trinity whose significant total unity has everything to do with life and death."72 The idea of a divine Trinity was important to Whitman too. He used it to describe the balance of an ideal world. ${ }^{73}$

In early July, Frank and Mildred went to Philadelphia for a brief visit with Horace and his wife Anne. They continued on to New York, Boston, and Nantasket Beach with just Horace. During this monthlong holiday Mildred once more became pregnant, and Horace gave her a copy of "The Proposal" by the American poet Bayard Taylor. ${ }^{74}$ In this poem the speaker recognizes marriage as spiritual and universal rather than restricted to a heterosexual couple and Christian ritual. Years earlier Taylor had said that he shared with Whitman "the awe and wonder and reverence and beauty of life, as expressed in the human body, with the physical attraction and delight of mere contact which it inspires." 75 Taylor was married, but some scholars now believe that he was homosexual or bisexual. By sending Mildred one of Taylor's love poems, Horace seems to have been pointing out the moral nature of various types of love just as Whitman did by publishing the "Calamus" poems and the "Children of Adam" poems in tandem in Leaves of Grass.

Frank and Mildred returned to Montreal in early August. Horace went with them and stayed until mid-October. Before Horace left, Frank began a campaign - which he maintained over the next six years-to raise money for Horace so that Horace would be free to focus on his many social and political causes. ${ }^{76}$ Two days after Horace left Montreal, Frank wrote: "Home again . . . after a long day of heart hunger for you ... found Mildred lying in the bed in your room and the light turned on and a beautiful warm glow over everything and she looked fine lying there as she always does ... but oh there was a terrible blank with you away. I keep listening for some sound of you in the other room or on the stairs." 77 Over the next few months, while Mildred and Horace certainly corresponded on their own, Frank provided Horace with daily reports on Mildred's pregnancy that included descriptions of her increasingly radiant beauty and his own longing for Horace to be with him and Mildred. In early November he wrote: "How I wish you were here ... Somehow I miss your love more Saturday nights and Sunday than any other time ... I dream of those [days] that are coming when we will all be together again." ${ }^{78}$ Despite Mildred's pregnancy and the Bains' and the Traubels' limited finances, Frank and Horace met at the Brevoort in New York in late December for a week. As soon as Frank 
returned, he and Mildred were begging Horace to come to Montreal so that the three of them could be together: "My heart sinks with longing. . . . Mildred wants you bad and we all need to be together. Some of these days that will come about for good. . . . I'd like to be able to see you go upstairs and into the room and see her lying there just like I did the other morning with her beautiful head and clear eyes outlined against the white pillow." 79

\section{The Birth of Betty Bain}

Horace arrived in mid-February and stayed until April $26^{\text {th }}$, four days after the home-birth of Betty Bain. He remained outside Mildred's bedroom during the labor and delivery. He later described this vigil in an explicit and highly emotional three-page poem, "In the Next Room," which he published in The Conservator. Traubel sat with "my heart in my mouth ... [f] eeling in my own nerves the hot drive and pull of pain." As soon as the baby was born he went into the room and, as the mother "reaches up to [the baby], she reaches to me, I too am included in her embrace." ${ }^{80}$ As Christine Stansell has noted, the early twentieth-century bohemian men and women of Greenwich Village, amongst whom Traubel must be counted, delighted in frank public discussions of childbirth even though the topic was considered inappropriate in most other circles $(84,275)$. Before Betty Bain's birth Horace had given Mildred The Century of the Child, a guide to modern child-rearing practices by the Swedish suffragist and feminist Ellen Key. After the birth he gave Mildred two poems. One was Whitman's "Joy, Shipmate, Joy!" in which the speaker says that life on earth with his "shipmate" or soul "is closed" after a "long, long anchorage." At the same time "our life begins" ( $L G, 501)$. Horace may well have been using this poem as a parallel to the initial difficulties Mildred had had in conceiving and her final success in producing a new life. The second poem was John Milton's "Ode on the Morning of Christ's Nativity," which begins with the Virgin Mary expressing fear that she has committed a sin by having a baby but then realizing that the birth was sacred. Mildred's child was equally sinless according to Whitman and Traubel's way of thinking. Horace gave Betty The Book of the Little Past by Josephine Preston Peabody, inscribed with "for B.B. April 22, 1912" and two lines from "In the Next Room." Two and a half years later, in a letter to Frank, Horace would again refer to the idea of a sacred Trinity in relation to the Bains and himself but would now include Betty: "[Frank] and Mildred and Betty-three in the one and me in the three of a blessedness beyond . . . confines." 81

Horace left Montreal four days after Betty's birth. A day later Frank wrote: "I've missed you Horace terribly. My heart was heavy last night 
there alone in the bed. I felt sometimes like I'd choke." In a second letter of the same day Frank said: "I feel like only half a man without you. Last night I had to take to the little room myself . . . [later] I sat on the bed with Mildred while taking a look at the baby now and then. Then I had to get out. I went down to Child's [Restaurant]. The boss said 'I guess you're feeling lonely tonight' . . . I guess he got on to the big lump in my throat." 82 While this letter sounds as if Frank's love was directed largely at Horace, other letters of the same period make it clear that Frank continued to cherish the Traubel-Bain Trinity. In one he explained that his heart was "always divided." 83

Likely because Betty Bain would have been only five weeks old at the end of May, Frank and Mildred did not attend the 1912 Walt Whitman memorial meeting, but Mildred composed five songs for it. One may have been directed to Horace: "My comrade, do you know how important you are to me?" In this poem the "comrade" is for the composer, the food she eats, the air she breathes, her dreams and faith, the blood in her veins, all space and time, all life and death. She "will go with you forever, / For nothing belongs to you or to me or today in gain or loss that does / Not belong to both of us in treasure forever." ${ }^{84}$ It is not unreasonable to assume that, on one level, the "treasure" was Betty.

In July Frank spent a day with Horace and Anne in Camden and then went on with Horace to Boston for a longer holiday. ${ }^{85}$ In August Horace travelled to Montreal for another two-month stay with Frank and Mildred. After he left, Frank and Mildred continued to press him to return and to express the loss they felt when Horace was not with them. Frank also sent Horace far more baby-news than one would expect one man to send to another in 1912 unless both men were intimately linked to the baby. In return Horace passionately denounced his home life with Anne and Gertrude in a letter to Frank: "The thing I haven't got here [in Camden], you and I and our wonder love. I am really ... . among aliens in a sense." ${ }^{86}$ In late December, Frank was anticipating a visit with Horace in New York. On December $26^{\text {th }}$ he wrote: "Three more days and ... I can see myself coming into your room there in the morning saying 'hi there time to get up' and then that towseled [sic] head bobbing up and the wide grey eyes." 87

\section{The "Eternal Flame" of Horace, Frank, and Mildred, 1913-1914}

In late January of 1913 Horace came to Montreal for another two-month visit. In early May Frank travelled to England on behalf of his bank. Before leaving Montreal Frank expressed his excitement about the time he would spend with Horace in New York before his ship set sail: "Three more days and then I'll be there with you for a few short hours and then away ... Y You'll be in bed [at the Brevoort] when I arrive. I'll 
go right up and raise you." ${ }^{88}$ After Frank completed his banking business in London, he went to see the Bolton Whitmanites and, with an introduction from Horace, went on to meet the French Whitmanite and homosexual Léon Bazelgette (1873-1928). Bazelgette toured Frank around Paris and Brittany. After Frank's ship docked in New York, he and Horace spent time together at the Brevoort. Then Frank returned to Montreal. By early July, Frank was urging Horace to come to Montreal: "I want to see you bad." ${ }^{89}$ Horace arrived in mid-July and stayed until mid-October. During this three-month period, with considerable assistance from Frank and Mildred, Horace completed volume three of With Walt Whitman in Camden although, as with Optimos, Horace could have done the work at home. In early October Charles Boni, one of Horace's Greenwich Village friends, published Mildred's short hagiographic biography, Horace Traubel. The day the author's copies arrived in Montreal Mildred gave one to Betty. Mildred's inscription and Horace's response to the inscription strengthen the suggestion that Horace fathered Betty Bain. Mildred wrote: "For Betty Bain, aged one year, five months and ten days . . May she grow to know the man of my story. He belongs in this household forever." ${ }^{90}$ Horace answered: "If [Betty] truly knew the man and the woman, the woman and the man, of this book, she must truly know herself for what she is in body and spirit." 91

In January of 1914 Mildred wrote a short loving poem to her daughter, "Whispers to Betty," which Horace published in The Conservator. ${ }^{92}$ In mid-February Horace returned to Montreal for two months. Toward the end of this visit he became ill. His condition worsened at home. He thought it would have improved if only he had stayed in Montreal: "You can realize what a difference it would make . . . if I were there." He described his relationship with Anne as commonplace and that with the Bains as not only extraordinary and preferable but also as everlasting and therefore spiritual: "Anne is beautiful to me, too, but ... it's more the normal not the unusual thing it is with us. You and Mildred and I have established ourselves as an eternal flame." ${ }^{93}$ Horace was not well enough to go to the annual Whitman meeting at the end of May in New York, but Frank went and then visited Horace in Camden. By August Horace had recuperated and was back in Montreal for a few weeks with the Bains. In September he returned and stayed until mid-October. ${ }^{94}$

\section{The Bains as Activists, 1913-1914}

By this time the Bains were well established Canadian Whitmanites. They had joined the Montreal Fabian Society, Labor Temple, and Equal Suffrage League where Mildred lectured on various social and political causes. She published some of these lectures and articles on 
similar topics in The Conservator. ${ }^{95}$ The Bains socialized with other Montreal Whitmanites such as Nathan and Lilian Mendelssohn and corresponded with Whitmanites in Canada, the United States, France, England, and Germany. In 1913 they hosted the American anarchist John William Lloyd on his return via Montreal to the United States after a visit with the Bolton Whitmanites. ${ }^{96}$ Traubel also introduced the Bains to the prominent American social reformers, Charlotte Perkins Gilman and Margaret Sanger. Mildred brought Gilman to lecture in Montreal in October of $1914 .{ }^{97}$ In November of the same year the Bains harboured Sanger from American authorities who were attempting to arrest her for promoting birth control. Frank, with his respectable position at the bank, was able to act as a guarantor so that Sanger could obtain a false passport in the name of Bertha Watson under which she fled to England. ${ }^{98}$ Sanger's diary entry for November 3, 1914, from aboard the R.M.S. Virginian, reads: "My [three days with the Bains have] left such a glow of love and good fellowship . . . Frank is one of the Christs of love . . . loyal and adoring Horace Traubel." 99 Decades later Sanger would remember the Bains' attachment to Carpenter's ideas in particular: "Among their other kindnesses [the Bains] gave me an introduction to Edward Carpenter" whom they "mentioned in awed tones" (Sanger, 121).

\section{Mildred's Fourth Pregnancy and the Birth of Paul Bain}

Horace continued to spend time with the Bains throughout $1915 . \mathrm{He}$ visited them in March in Montreal and in April and July in Brantford, Ontario, a small town sixty-five miles west of Toronto where Frank had been transferred with the bank. Horace returned to Brantford in mid-August and stayed until early October. In late February of 1916 he came back for another two months, during which Mildred became pregnant. Likely because of Mildred's condition she and Frank attended the first meeting of the Toronto chapter of the Walt Whitman Fellowship on May $31^{\text {st }}$ rather than going to New York. Mildred sang a Whitman and a Traubel poem, both of which she had set to music. ${ }^{100}$ In mid-August Horace returned to Brantford where he remained until early October. Mildred's son, Paul Bain, was born on December 8, 1916, at 11:30 p.m. Frank wrote Horace moments later, before he went to see Mildred and Paul. In this letter Frank described intimate details of the event including Mildred's water breaking on the stairs before they left for the hospital. Frank then visited Mildred and Paul but was home by 1 a.m. and wrote Horace a second letter. ${ }^{101}$ When Paul turned fifteen Mildred gave him a copy of Horace's Optimos in which she wrote: "A copy of this book just naturally belongs to you, dear Paul, because of your relation to us and our relation to Horace." ${ }^{102}$ Again the idea of a 
Trinity - or two overlapping Trinities-is invoked as well as an important relationship between Paul and Horace.

Throughout the summer of 1917 Mildred sent Horace a number of loving letters filled with details of Betty and Paul's activities, discussions of Horace's upcoming visits, and expressions of her and Frank's desire to "have you to ourselves." In one, Mildred tells Horace that Betty stirs with a spoon the same way he does. In another, Mildred laughingly says that Betty had found her "douche attachments" and wanted to know what they were. It is difficult to imagine that a woman would have discussed such matters with a man with whom she was not intimately involved. Mildred also asked Horace if he would like to have Paul's crib in his room when he came to stay, an unusual arrangement for any house guest who was not closely connected to the child. ${ }^{103}$ Betty, now age five, was writing to Horace herself. ${ }^{104}$ Horace was responding with books, postcards, and equally loving letters. Likely because Horace's health was not good he did not visit as much in 1917, but letters confirm that his relationship with the Bains was as intense as ever. $\mathrm{He}$ also managed to spend about two weeks with them in August. After he was gone he was, for Frank, "in my mind all the time."105

\section{The Bains and the Whitman Club of Bon Echo, 1918-1919}

In the spring of 1918 Frank's bank transferred him to Hamilton, Ontario, a small city forty-five miles west of Toronto. Frank visited Horace in New York in March and May. In June the Bains holidayed at "The Whitman Club of Bon Echo" located on a wilderness property of 1600 acres about forty miles north of Belleville, Ontario. Toronto psychic and social and political activist Flora MacDonald Denison (1867-1921) had purchased Bon Echo complete with rustic hotel in 1910. In late 1915 she began to focus on Whitman's writings as support for her various causes and to think of organizing Bon Echo as a cult center to Whitman. In early 1916 MacDonald (as she called herself professionally) met Traubel for the first time. Shortly afterwards she met the Bains. By May she had established "The Whitman Club" with its small journal, The Sunset of Bon Echo, and become a founding member and Vice-President of the Toronto branch of the Walt Whitman Fellowship. ${ }^{106}$

According to MacDonald - and many English Canadians of this period-anyone who spent time in Canada's wilderness would easily absorb the spirituality of nature and the native people who had once lived there and so would become a "wild Indian."107 MacDonald believed, therefore, that all Whitmanites would be drawn to Bon Echo even though Whitman and Traubel saw the city and the country as equally spiritual and preferred to live in the city, while Whitman, at 
least, regarded Native North Americans as an inferior race that would likely die out in the face of modern life. ${ }^{108}$ Traubel rejected MacDonald's invitation to come to Bon Echo in 1916, 1917, and 1918. However, as soon as the Bains returned from Bon Echo in 1918, Horace went to stay with them in Hamilton from mid-July to late August. Horace's health was deteriorating, and he required medical care which Frank and Mildred provided despite Anne's pleas for them to send Horace home where she would care for him. ${ }^{109}$

In the spring of 1919 Frank's bank transferred him to Havana, Cuba. Mildred, Betty, and Paul were to join him in the fall. Horace intended to spend the winters with them. ${ }^{110}$ Before Frank left for Cuba he visited Horace and Anne in New York, where they were staying with Whitmanite friends David and Rose Karsner. Karsner, a writer and newspaper journalist, was in the midst of preparing a glowing biography of Horace. In late June, Mildred, Betty, and Paul went to Bon Echo, where Mildred served as secretary of "The Whitman Club," while MacDonald focused on the centennial celebration of Whitman's birthday she had been planning for three years. Naturally MacDonald invited Horace. This time he came, although, according to Karsner, it was not the celebration that "lured him." Rather, "the greater joy of being with the Bains, in what he might have thought were his last days on earth, cheered and buoyed him." 111 Frank stopped in New York on July $29^{\text {th }}$ en route from Cuba to bring Horace, Anne, and Horace's friend, David Cummings, to Bon Echo. ${ }^{112}$ They arrived on August $4^{\text {th }}$. Then, to Flora's disappointment and likely Anne's, Traubel favored Mildred as his nurse. On August $25^{\text {th }}$ the Traubels, the Bains, Cummings, the Saunders, MacDonald, MacDonald's son Merrill Denison, and a few other Whitmanites went out in three boats to dedicate a large granite rock in Bon Echo's Lake Mazinaw to Whitman's democratic ideals. MacDonald planned for the rock to be inscribed with the following lines from Whitman's "Song of Myself": "My foothold is tenon'd and mortised in granite / I laugh at what you call dissolution / And I know the amplitude of time" $(L G, 48)$. The Bains left Bon Echo on the $29^{\text {th }}$ to visit family in Ontario. Horace died at Bon Echo on September $8^{\text {th }}$.

\section{Frank and Mildred's Lifelong Commitment to Whitman and Traubel}

Frank and Mildred continued to work for Traubel's causes over the next four decades. Frank helped to organize and pay for Traubel's funeral and raise money for a headstone. In the summer of 1920 the Bains attended MacDonald's second dedication of the rock in Lake Mazinaw with its sculpted Whitman text (see the photo on the back cover). Although MacDonald died in May of 1921, the Bains spent 
their summer holidays of 1921 and 1922 at Bon Echo. In 1922, after a transfer with the bank from Havana to Toronto, Frank and Mildred's leftist politics led them to associate with Tim Buck (1891-1973), an English immigrant and founding member of the Communist Party of Canada in 1921. Mildred wrote a regular column for the CPC's journal, The Masses, throughout the 1920s. In 1925 she visited the Bolton Whitmanites and Bazelgette in France. In 1929, after suffering for at least three years from some sort of lethargy that may well have resulted from the loss of Horace, Frank took a medical leave of absence and went with Mildred to see the Bolton Whitmanites and Bazelgette. ${ }^{113}$

In 1933 Frank took early retirement from the bank. A year later he and Mildred purchased their Arts and Crafts-style house in Toronto, installed their Whitman/Traubel collection, and planted the Whitman lilac-shoots provided by the Saunders. In 1936, in reference to a holiday spent the previous summer at a relative's cottage near Bon Echo, Frank said in a letter to Anne Traubel: "[I have] always wished some day to have a shack of our own up there across from the big rock. It's the spot I'm most fond of."'114 In 1938 the Bains purchased Stanley Island. Clearly it was the fulfillment of a dream. It was "a little Bon Echo" of their own. Perhaps it was even better since, although it was not close to Bon Echo, Whitman had once "passed this way."

On May 21, 1939, Frank began his Stanley Island Log-book. His first entry was a quote from Thoreau, who had once met Whitman: "An island always pleases my imagination, even the smallest, as a small continent and integral portion of the globe. I have a fancy for building my hut on one." 115 In June, Frank found a large granite rock on the mainland and brought it to Stanley. He said it was a reminder of Whitman's sense of the "amplitude of time" and so of the rock at Bon Echo. Frank then discovered the Indian name for Stanley Island, Manatoana, and wrote, with knowledge of Whitman's interest in ancient cultures, "How Walt would have liked that." "116 The following summer Frank told Anne that he and Mildred had "built our little log cabin. ... The shore in the distance to the left is Wellesley island, American side. . . . I have a notion from reading Walt's Canadian diary that it must have been somewhere around [there] that Walt spent ten days or so." ${ }^{117} \mathrm{He}$ also noted in the Log-book that the lilac shoots he had planted the year before were blooming for Walt's birthday. Invited to the dedication of the Walt Whitman house on Long Island as a heritage site in 1952, Frank gave a short speech in which he acknowledged the source of his Toronto and Stanley Island lilacs which had now "grown lusty."118 Until their respective deaths in 1959 and 1962, Frank and Mildred maintained their relationships with Merrill Denison, the Saunders, the Mendelssohns, several of the Bolton Whitmanites, Bazelgette, 
and Anne and Gertrude Traubel. They also corresponded with other Whitmanites and social and political activists such as Shigetaka Naganuma, Ella Reeve Bloore, and Tom Mann. From time to time they sent money to Anne. ${ }^{119}$

\section{Conclusions}

While I have concluded largely on the basis of written texts that Horace Traubel and Frank and Mildred Bain employed their understanding of Whitmanian comradeship to sanctify their sexual relationship and Horace's fathering of Mildred's two children, and that this relationship may give us some further insight into interpretations of Whitman's sexuality, some scholars will invoke a familiar caveat, namely, not to give current interpretations to language that belongs to earlier times. To avoid this error, it is helpful to compare Horace's letters to Frank to Horace's letters to male Whitmanites with whom it seems unlikely Horace had a sexual relationship, such as Paul Fournier, William F. Gable, and Marsden Hartley. In fact, the latter correspondence contains none of the intensity of feeling of the former. Similarly, Frank's letters to other Whitmanites are entirely "chatty" apart from the use of terms like "dear comrade."

At the same time many of the letters in the Horace and Anne Montgomerie Traubel papers in the Library of Congress suggest that Horace conducted his extra-marital relationships with some sense of openness. According to Michael Robertson, Anne Traubel gave no indication of knowing "upon whom her husband bestowed his overflowing love" (268). However, Anne knew Philip Dalmas and Rosalie Goodyear and was aware of Horace's feelings, at least, for Wiksell and the Bains. Letters she sent to Horace when he was staying with Wiksell in Boston in 1907 seem to acknowledge Wiksell as a lover. In one, Anne says that she understood that Horace was "torn," but that when he returned home she expected his "eyes to look forward and not back." "120 In another, while discussing Horace's feelings for Wiksell, she used highly erotic language to remind Horace of the passionate nature of their own love. In letters Anne sent to Horace while he was staying with the Bains, she frequently asked him to come home. ${ }^{121}$ One summer she even threatened to come to Montreal and bring him back home. ${ }^{122}$ In a 1918 letter to Gertrude, Anne seethed as she described Frank as an "underhanded" banker "all the while sweetly and smilingly protecting his own interests and coming out to the good." 123 Anne's many letters to Horace over these years also regularly complain about the frequency and length of his absences, not knowing when he would return home, raising Gertrude in a sense on her own, and spending holidays year after year without him. Anne also expressed concern about the Traubel finances, which 
were in a sorry state partly as a result of Horace's frequent and lengthy visits to "comrades."

At the same time, Wiksell and Goodyear knew a great deal about Horace's relationship with the Bains. Percy accepted it graciously, Goodyear less so. ${ }^{124}$ But, as good Whitmanites - or bohemian moderns - they all seemed to have believed that free-love and love-children were steps toward a more moral society. For them, Whitmanian comradeship apparently included a spectrum of heterosexual and homosexual relationships within and outside the bonds of marriage. As Mildred astutely stated, Walt Whitman's poems were "secretly hugged to the breast of the average repressed, sexually furtive member of society." ${ }^{25}$ Mildred admitted that she had once been one of these furtive members of society, but Whitman via Traubel had enlightened her so that her body was no longer "shackled" and "cramped." She was then able to perceive "the full glories of the body and the soul as equally God-given" and so could "be a wife to more than my husband ... . a lover to all." She could "gently loosen ... [ $\mathrm{t}$ ] he bloodless clinging fingers of tradition $\ldots$.. [a] nd hereafter . . . give my love freely and naturally to man as well as woman." 126

\section{Nova Scotia College of Art E Design}

\section{NOTES}

1 Walt Whitman, Daybooks and Notebooks, ed. William White (New York: New York University Press, 1978), 3:629; Richard Maurice Bucke, Walt Whitman (Philadelphia: D. McKay), 60; and R.M. Bucke, letter to Jessie Bucke, August 2, 1880, in Richard Maurice Bucke, Medical Mystic: Letters of Dr. Bucke to Walt Whitman and his Friends, ed. Artem Lozynsky (Detroit: Wayne State University Press, 1977), 73.

2 Frank Bain, postcard to Horace Traubel, October 22, 1908, Horace Traubel and Anne Montgomerie Traubel Papers, Library of Congress, Box 49; hereafter HT/AMT Papers, LC. Frank sent this postcard to Horace while on a trip through the Thousand Islands. On it he wrote, with reference to the 1904 publication of Whitman's diary, "Walt must have passed this way."

3 Walt Whitman, Leaves of Grass: Comprehensive Reader's Edition, ed. Harold W. Blodgett and Sculley Bradley (New York: New York University Press, 1965), 723. Hereafter, $L G$.

4 Walt Whitman, "One of the Lessons Bordering Broadway. The Egyptian Museum," New York Dissected: A Sheaf of Recently Discovered Newspaper Articles by the Author of Leaves of Grass, ed. Emory Holloway and Ralph Adimari (New York: Rufus Rockwell Wilson, 1936), 25-40; Stephen J. Tapscott, "Leaves of Myself: Whitman's Egypt in 'Song of Myself'," American Literature 2 (March 1978), 49-73; and Rosemary L. Gates, "Egyptian Myth and Whitman's 'Lilacs'," Walt Whitman Quarterly Review 5 (Summer 1987), 21-30. 
5 Michael Robertson, Worshipping Walt. The Whitman Disciples (Princeton: Princeton University Press, 2008), 289.

6 Henry Scholey Saunders (1864-1951) became a follower of Whitman in 1910 and the first president of the Toronto chapter of the Walt Whitman Fellowship in 1916. See Elsie Pomeroy, William Saunders and His Five Sons: The Story of the Marquis Wheat Family (Toronto: Ryerson Press, 1956), 122-133.

7 F. Bain, note to Betty and Paul Bain, ts., Bain Family Archive, Box 2; hereafter BFA. F. Bain, entry, May 31, 1940, Stanley Island Log-book, BFA.

8 Traubel associated with members of the Roycrofters, an Arts and Crafts community in Aurora, New York, and strongly supported the Rose Valley Arts and Crafts community near Philadelphia. He published the latter's journal, The Artsman (19031907) and regularly contributed to it. The Bains had a complete run of The Artsman in their Toronto home.

9 Clarence Hudson White was a co-founder, with Alfred Stieglitz, of the PhotoSecession movement in 1902. William F. Gable, an Altoona, Pennsylvania, department store owner, and Arthur Goodwin, a Boston artist, were Whitmanites and friends of Traubel. Traubel purchased Japanese prints at Bunkio Matsuki's in Boston as early as 1907. See H. Traubel, letter to Anne Traubel, August 5, 1907, HT/AMT Papers, LC, Box 9. Traubel may have been influenced by Whitman's interest in Japan and/ or contemporary interest in Japanese art. See Whitman, "A Broadway Pageant," LG, 242-246, and David Scott, "Diplomats and Poets: 'Power and Perception' in American Encounters with Japan, 1860," Fournal of World History 17 (September 2006), 297-337.

10 The Bains sold some of their Whitman material to Charles Feinberg in the 1950s. It then went to the Library of Congress. The rest remains with the Bains' grandson, Brian Bain Caldwell, who kindly gave me access to it.

11 American scholarship sees Flora MacDonald Denison as the leader of Canadian Whitmanites. For example, Robertson says that she met Traubel when he was staying with the wealthy Bain family in Toronto, and that Traubel's interests were shared "by no one more fervently" than MacDonald Denison (273). In fact, Flora did not meet Traubel until 1916, and then at the home of Toronto spiritualist and medical doctor Albert Durrant Watson (1856-1926). She met the Bains shortly afterward. The Bains lived in Brantford then, not Toronto, and were never wealthy.

12 Walt Whitman, The Correspondence, ed. Edwin Haviland Miller (New York: New York University Press, 1969), 5:203.

13 Walt Whitman, Prose Works 1892, ed. Floyd Stovall, (New York: New York University Press, 1964), 2:414-415. Hereafter, $P W$.

14 Horace Traubel, "Collect," The Conservator 4 (March 1893), 7.

15 Horace Traubel, "Collect," The Conservator 15 (April 1904), 19.

16 Quoted in Bryan K. Garman, “'Heroic Spiritual Father:' Whitman, Sexuality and the American Left, 1890-1940," American Quarterly 52 (March 2000), 103.

17 Juan A. Herrero Brasas, Walt Whitman's Mystical Ethics of Comradeship: Homosexuality and the Marginality of Friendship at the Crossroads of Modernity (Albany: State University of New York Press, 2010), 6. 
18 Horace Traubel, review of The Intermediate Sex: A Study of Some Transitional Types of Men and Women by Edward Carpenter, The Conservator 23 (February 1913), 188-189. See also Traubel's review of Carpenter's Intermediate Types Among Primitive Folk, The Conservator 25 (January 1915), 173. Both of these books were published by Traubel's New York friend, political and social activist Mitchell Kennerley.

19 Anne Traubel, letter to Horace Traubel, August 15, 1907, HT/AMT Papers, LC, Box 8.

20 Joann P. Krieg, "Without Walt Whitman in Camden," Walt Whitman Quarterly 14 (Fall 1996), 85-112; Harry G. Cocks, "Calamus' in Bolton: Spirituality and Homosexual Desire in Late Victorian England," Gender \& History 13 (August 2001), 210-216; and Cocks, Nameless Offences: Homosexuality in the Nineteenth Century (I.B. Tauris, 2003), 163-164.

21 Garman, 105; Robertson, 268-272. See also Ed Folsom, "Foreword," in Horace Traubel, With Walt Whitman in Camden, vol. 9 (Oregon House, CA: W. L. Bentley, 1996), xx-xxi. The erotic nature of Wiksell's letters to Traubel up to 1907 as well as a poem Wiksell wrote suggest that the relationship ended in 1907. See Wiksell, letters to Horace Traubel, 1907, HT/AMT Papers, LC, Box 109; and Wiksell, "And Now Peace Came," The Conservator 18 (March 1907), 4. Not all scholars believe that Traubel and Wiksell had a sexual relationship. See Herrero Brasas, 152. Rosalie Goodyear was the granddaughter of Charles Goodyear, the inventor of the vulcanization of rubber, and the daughter of William H. Goodyear, an art curator at the Brooklyn Museum.

22 For Fournier's friendship with Traubel, see Marie Via and Marjorie Searl, Head, Heart, and Hand: Elbert Hubbard and the Roycrofters (Rochester: University of Rochester Press, 1994), 131; and P. Fournier, letters to Horace Traubel, HT/AMT Papers, LC, Box 66.

23 The frequency of Horace's visits to New York is well established throughout correspondence in the HT/AMT Papers, LC. For a reference to Horace's lectures at the Liberal Club in Greenwich Village, see Christine Stansell, American Moderns: Bohemian New York and the Creation of a New Century (Princeton: Princeton University Press, 2010), 84. There are three photographs of Traubel taken by Fournier in 1909 in the BFA.

24 Goodyear, "Defiant Dreamers," American Archives of Art, Box 2, File 1, 14c, 14d. Hereafter, AAA.

25 Goodyear, letter to Horace Traubel, December [?] 1909, HT/AMT Papers, LC, Box 73.

26 Goodyear, "Defiant Dreamers, AAA, Box 2, File 1, 14d.

27 Goodyear, letter to Horace Traubel, March 3, 1910, HT/AMT Papers, LC, Box 73.

28 Between 1911 and 1913 Goodyear wrote love poems for The Conservator that she later said had all been addressed to Traubel. In early 1912 Goodyear left Fournier and moved to New York. In 1913 she stopped communicating with Traubel in anger over his lack of interest in her and Horatia. She resumed communication and poetry contributions in 1916 (soon after Horatia died) but ended the relationship completely in 1917. See Goodyear, letters to Horace Traubel, 1910 to 1913 and 1916 to 1917, HT/ AMT Papers, LC, Box 73; Goodyear, "Defiant Dreamers," AAA, Box 2, 14d; and, as an example of Goodyear's poems to Traubel, "The Eternal You," The Conservator, 22 (February 1911), 182. 
29 Information on the Jackson and Bain families may be found in the Flora MacDonald Denison Papers, Thomas Fisher Archives, University of Toronto (hereafter, FMD Papers/UT); and the Merrill Dennison Papers, Queen's University, Kingston, Ontario (hereafter, MD Papers/QU); and in the BFA.

30 Richard Maurice Bucke, Cosmic Consciousness (New York: Dutton, 1924), 10.

31 Frank Bain, “A Record for the Children,” ts., February 1946, BFA, Box 2.

32 From statements made about Mildred in Frank and Horace's letters to each other, it is clear that Mildred and Horace corresponded frequently. The almost daily letters that Mildred wrote to Horace in the summer of 1917-which inexplicably ended up in the BFA - provide a clear sense of the frequency and intimacy with which she wrote. Since Horace kept so many letters from so many people, it is difficult to imagine that he did not keep Mildred's, but no explanation for their disappearance has surfaced.

33 Frank Bain, letters to Horace Traubel, 1905 and 1906, HT/AMT Papers, LC, Box 49.

34 For example, see Frank Bain, letters to Horace Traubel, December 18 and 27, 1906, HT/AMT Papers, LC, Box 49. Information about money sent by Frank Bain to Horace Traubel from 1907 to 1919 is found throughout letters from Frank Bain to Horace and Anne Traubel in HT/AMT Papers, LC and in BFA.

35 Frank Bain, letter to Horace Traubel, March 10, 1907, HT/AMT Papers, LC, Box 49.

36 Mildred Bain, "Oh Dear New Comrade," The Conservator 18 (September 1907), 100-101. Mildred Bain wrote regularly for The Conservator from 1907 until 1918.

37 Mildred Bain, letter to Horace Traubel, November 18, 1907, HT/AMT Papers, LC, Box 24.

38 For an excellent discussion of bohemian life in Greenwich Village in the early twentieth century, see Stansell.

39 Frank Bain, letter to Horace Traubel, June 25, 1908, HT/AMT Papers, LC, Box 49.

40 Frank Bain, letter to Horace Traubel, December 6, 1908, HT/AMT Papers, LC, Box 33.

41 Cyril Greenland and John Robert Colombo describe the Bains as "Traubelites" in Walt Whitman's Canada (Willowdale, Ontario: Hounslow Press, 1992), 158.

42 Frank Bain, letter to Horace Traubel, April 30, 1909, HT/AMT Papers, LC, Box 49.

43 For a discussion of homosexuality and the Bolton Whitmanites, see Robertson, 198-231.

44 Frank Bain, letter to Mildred Bain, July 16, 1909, Box 2, BFA.

45 Edward Carpenter's From Adam's Peak to Elephanta was first published in 1892 by Swann Sonnenschein, London. Frank Bain's copy is the 1903 edition by G. Allen and Unwin, London.

46 Mildred Bain, “Love Said to Me,” The Conservator 20 (May 1909), 86. 
47 Mitchell Kennerley, Modern Love: An Anthology (New York: Mitchell Kennerley, 1906); Anita Gabrielle Lavrack, "The Right Voice," Smart Set: A Magazine of Cleverness 29 (September 1909), 146.

48 Frank Bain, letter to Horace Traubel, October 31, 1909. HT/AMT Papers, LC, Box 49.

49 Frank Bain, letter to Horace Traubel, November 21, 1909. HT/AMT Papers, LC, Box 49.

50 Frank Bain, letter to Horace Traubel, May 10, 1911, HT/AMT Papers, LC, Box 50.

51 Frank Bain, letter to Horace Traubel, February 3, 1910, HT/AMT Papers, LC, Box 49.

52 Frank Bain, letter to Horace Traubel, February 21, 1910, HT/AMT Papers, LC, Box 49.

53 Frank Bain, letter to Horace Traubel, March 30, 1910, HT/AMT Papers, LC, Box 49.

54 Frank Bain, letter to Horace Traubel, April 27, 1910, HT/AMT Papers, LC, Box 49.

55 Frank Bain, letter to Horace Traubel, May 26, 1910, HT/AMT Papers, LC, Box 49.

56 Frank Bain, letter to Horace Traubel, June 4, 1910, HT/AMT Papers, LC, Box 49.

57 Anne became "Associate Editor" of The Conservator in 1898 and Gertrude "Work Editor" in 1906.

58 Horace Traubel, letter to Marsden Hartley, August 13, 1910, Heart's Gate: Letters Between Marsden Hartley and Horace Traubel, 1906-1915, ed. William Innes Homer (Highlands, North Carolina: The Jargon Society, 1982), 74.

59 Wiksell, letter to Horace Traubel, July 18, 1910, HT/AMT Papers, LC, Box 109. Stansell notes that the bohemians of Greenwich Village did not feel comfortable talking about homosexual relationships even though they openly discussed free love amongst heterosexuals (250).

60 Horace Traubel, letter to Frank Bain, September 17, 1910, BFA, Box 5.

61 Horace Traubel, letter to Frank Bain, September 25, 1910, BFA, Box 5.

62 Horace Traubel, letters to Frank Bain, September 30, October 2, October 5, 1910, BFA, Box 5.

63 Frank Bain, letter to Horace Traubel, September 30, 1910, HT/AMT Papers, LC, Box 49.

64 Frank Bain, letter to Horace Traubel, October 5, 1910, HT/AMT Papers, LC, Box 49.

65 Horace Traubel, letter to Frank Bain, October 7, 1910, BFA, Box 5.

66 Frank Bain, letter to Horace Traubel, January 2, 1911, HT/AMT Papers, LC, Box 50. 
67 Frank Bain, letter to Horace Traubel, February 20, 1911, HT/AMT Papers, LC, Box 50.

68 Frank Bain, letter to Horace Traubel, March 29, 1911, HT/AMT Papers, LC, Box 50.

69 Frank Bain, letter to Horace Traubel, May 18, 1911, HT/AMT Papers, LC, Box 50.

70 Horace Traubel, telegram to Frank Bain, May 20, HT/AMT Papers, LC, Box 50.

71 Frank Bain, letter to Horace Traubel, June 7, 1911, HT/AMT Papers, LC, Box 50.

72 Horace Traubel, letter to Frank Bain, June 8, 1911, HT/AMT Papers, LC, Box 50.

73 For a discussion of Whitman's use of "trinity" and "trinitas," see Martin K. Doudna, “The Essential Ultimate Me': Whitman's Achievement in 'Passage to India," Walt Whitman Quarterly Review 2 (Fall 1984), 1-9.

74 Bayard Taylor, "The Proposal," The Poems of Bayard Taylor (Boston: Ticknor and Fields, 1865), 257.

75 Quoted in Gary Schmidgall, Walt Whitman: A Gay Life (New York: Penguin Group, 1997), 126.

76 Frank Bain sent his first requests to Whitmanites for funding for Traubel on August 18th, 1911. Over the first year he collected $\$ 1,285$. In subsequent years he collected less and less. There are no records dated after 1917. The responses and carbon copies of the requests are in BFA, Box 5 .

77 Frank Bain, letter to Horace Traubel, October 17, 1911, HT/AMT Papers, LC, Box 50.

78 Frank Bain, letter to Horace Traubel, November 4, 1911, HT/AMT Papers, LC, Box 50 .

79 Frank Bain, letters to Horace Traubel, January 6, 12, 27, 1912, HT/AMT Papers, LC, Box 50.

80 Horace Traubel, "In the Next Room," The Conservator, 23 (April 1912), 20-22.

81 Horace Traubel, letter to Frank Bain, November 24, 1915, BFA, Box 5.

82 Frank Bain, letter to Horace Traubel, April 26, 1912, HT/AMT Papers, LC, Box

50. Child's was one of Frank's and Horace's favorite restaurants in Montreal.

83 Frank Bain, letter to Horace Traubel, June 4, 1912, HT/AMT Papers, LC, Box 50.

84 Mildred Bain, "My comrade, do you know how important you are to me?," ts., BFA, Box 2.

85 Frank Bain, letter to Horace Traubel, August 1, 1912, HT/AMT Papers, LC, Box 24.

86 Horace Traubel, letter to Frank Bain, December [?], 1912, Box 5. BFA.

87 Frank Bain, letter to Horace Traubel, December 26, 1912, Box 51. HT/AMT Papers, LC.

88 Frank Bain, letter to Horace Traubel, May 10, 1913, HT/AMT Papers, LC, Box 51.

89 Frank Bain, letter to Horace Traubel, July 3, 1913, HT/AMT Papers, LC, Box 51. 
90 This copy of M. Bain's Horace Traubel is in BFA.

91 Horace Traubel, letter to Mildred Bain, October 20, 1913, BFA, Box 2.

92 Mildred Bain, "Whispers to Betty,” The Conservator 24 (January 1914), 164.

93 Horace Traubel, letter to Frank Bain, May 6, 1914, BFA, Box 5.

94 Robertson says that, because of illness, Traubel saw less of "everyone" after 1914 (272). As this essay demonstrates, however, he saw the Bains relatively frequently and for long periods of time between 1914 and his death in 1919.

95 For examples, see Mildred Bain, "The Power of Personality," a paper given before the Women's Art Society in Montreal, January 10, 1911, and published in The Conservator 12 (April 1911), 22-24; "Votes for Women," a paper read before the Equal Suffrage League, Montreal, 1913, and published in The Conservator 14 (November 1913), 134-136; "Horace Traubel's Message to Women," written for a Montreal symposium on women and suffrage, and published in The Conservator 14 (December 1913), 149151; "The Red Flag in Music," a speech given in Montreal in 1915 (venue unknown), and published in The Conservator 16 (June 1915), 54-55, and 16 (July 1915), 69-70.

96 Wendy McElroy, "A Brief Sketch of the Life of J. William Lloyd," available online at: http://www.wendymcelroy.com/print.php?news.1875. Frank corresponded with Lloyd as early as 1910 after an introduction from Traubel. See J. W. Lloyd, letter to Frank Bain, March 28, 1910, BFA, Box 2.

97 Charlotte Perkins Gilman, letter to Mildred Bain, October 3, 1914, FMD Papers/ UT, Box 6. Since Mildred Bain and Flora MacDonald Denison did not meet until 1916, and since Flora was such a great follower of Gilman, it seems likely that Mildred gave the 1914 Gilman letter to Flora as a souvenir.

98 Margaret Sanger, Margaret Sanger: An Autobiography (New York: Dover Publications, 1938), 121.

99 Esther Katz, ed., The Selected Papers of Margaret Sanger (Urbana and Chicago: University of Illinois Press, 2003), 1:97.

100 Henry Saunders, letter to Horace Traubel, June 1, 1916, HT/AMT Papers, LC, Box 99.

101 Frank Bain, letters to Horace Traubel, December 8, December 9, 1916, Box 51. HT/AMT Papers, LC, Box 51.

102 This copy of Optimos is in BFA.

103 Mildred Bain, letters to Horace Traubel, June 23, July 2, 8, 17, 1917. BFA.

104 Betty Bain, letters and drawings to Horace Traubel, HT/AMT Papers, LC, Box 51.

105 Frank Bain, letter to Horace Traubel, October 7, 1917, HT/AMT Papers, LC, Box 51.

106 The timing of MacDonald's interest in Whitman and the formation of "The Whitman Club of Bon Echo" is documented in letters of December 1915 and January and February of 1916 to and from MacDonald's son, Merrill Denison, in MD Papers/ QU, Box 10. See also Deborah Gorham, "Flora MacDonald Denison: Canadian Feminist," in Linda Keeley, ed., A Not Unreasonable Claim: Women and Reform in Canada, 1880s-1920s (Toronto: Women's Press, 1979), 47-70; Ramsay Cook, "Nothing Less 
Than a New Theory of Art and Religion," Provincial Essays 7 (1989), 5-16; and Mary Savigny, Bon Echo: The Denison Years (Toronto: Natural Heritage Books, 1997).

107 MacDonald, letter to Horace Traubel, September 24, 1916, HT/AMT Papers, LC, Box 85.

108 For Whitman's love of the urban, see $P W, 2: 371$. For Whitman's views on Native Americans, see Ed Folsom, Walt Whitman's Native Representations (New York: Cambridge University Press, 1994), Chapter Three.

109 Frank Bain, letter to Anne Traubel, July 20, 1918, HT/AMT Papers, LC, Box 24.

110 Frank Bain, letter to J. Wallace, February 5-7, 1919. File Eng1186/1/17, Papers Relating to J.W. Wallace and the Bolton Whitman Fellowship, John Rylands Library, University of Manchester.

111 David Karsner, Walt Whitman (New York: Egmont Arens, 1919), 34.

112 David Cummings was a New York Whitmanite who wrote for several left-wing newspapers and journals. See Cummings, letters to Horace Traubel, HT/AMT Papers, LC, Box 61.

113 Frank Bain, letters to Royal Bank medical staff, 1928 to 1929, BFA, Box 5.

114 Frank Bain, letter to Anne Traubel, January 6, 1936, HT/AMT Papers, LC, Box 24.

115 Frank Bain, dedication page, Stanley Island Log-book. BFA.

116 Frank Bain, entries, June 18 and August 18, 1939, Stanley Island Log-book. BFA.

117 Frank Bain, letter to Anne Traubel, May 20, 1940, HT/AMT Papers, LC, Box 24.

118 Frank Bain, ts., 1952, BFA, Box 5.

119 BFA has photos of the Bains with Bloore and with Mann and correspondence between the Bains and Bazelgette, Naganuma, Bloore, and Mann.

120 Anne Traubel, letter to Horace Traubel, March 24, 1907, HT/AMT Papers, LC, Box 8 .

121 See Anne Traubel, letters to Horace Traubel, HT/AMT Papers, LC, Boxes 8, 9,10 , and 19 .

122 Anne Traubel, letter to Horace Traubel, September 22, 1911, HT/AMT Papers, LC, Box 9.

123 Anne Traubel, letter to Gertrude Traubel, January 3, 1918, HT/AMT Papers, LC, Box 19.

124 Rosalie expressed some jealousy of the Bains in letters to Horace Traubel, February 21 and March 18, 1912, HT/AMT Papers, LC, Box 73; and "Defiant Dreamers," AAA, Box 2, Files 2, 35.

125 Mildred Bain, "A few words to Morris Lychenheim," The Conservator, 29 (October 1918), 124.

126 M. Bain, "Oh Dear New Comrade," The Conservator 18 (September 1907), $100-101$. 